Ann. Biol. anim. Bioch. Biophys., 1979, 19 (1 B), 241-250.

\title{
Effects of undernutrition during late pregnancy on gluconeogenesis and ketogenesis in twin-pregnant ewes
}

\author{
par C. RÉMÉSY, C. DEMIGNÉ
}

Station de Maladies méfaboliques, I.N.R.A., Theix, Saint-Genès-Champanelle, 63110 Beaumont, France.

Summary. This study reports the interaction of protein and lipid mobilization on gluconeogenesis and ketogenesis after diefary restriction of ewe at the end of pregnancy. Two experiments were carried out using twin-pregnant Limousine ewes which were underfed either for the last 14 weeks or the last 4 to 6 weeks of pregnancy, depending on the lot ( 80 to 100 p. 100 of maintenance needs). Energy ingested at the end of pregnancy had much more marked effect on lamb weight at birth than body reserves midway through pregnancy. On the other hand, ketosis sensitivity was inversely proportional to dam weight gain during the first two-thirds of pregnancy. Amino acids were limiting factors of maternal gluconeogenesis when propionic acid level was low. This was expressed by a drop in some glucogenic amino acids, especially alanine, during undernutrition. On the other hand, glycine rose and variations in essential amino acids were limited. Protein mobilization was higher in the « high-low » lots than in the « low » lots, resulting in lower ketogenesis in the « high-low » lots for the same concentration of plasma free fatty acids. At the end of pregnancy, plasma acetate rose parallel to ketone bodies following endogenous production and less utilization by peripheric tissues.

\section{Introduction.}

In the ewe, undernourishment during pregnancy influences lamb birth weight (Russel, Doney and Reid, 1967). In addition, multiple-bearing ewes may present clinical signs of pregnancy toxaemia (Reid, 1968). One of the main problems is the effect of body reserves on the response to undernourishment during late pregnancy and maximal foetal growth (Robinson ef al., 1977). Overfat ewes are probably the most responsive to various stresses (nutritional and other), and the high mobilization of body fat reserves increases the risk of ketosis and fatty liver; but these ewes are also likely to have the highest protein reserves. The aim of this work is to show the interaction of fat or protein mobilization on gluconeogenesis and ketogenesis after dietary restriction.

\section{Experimental procedure.}

Animals and diets. - Limousine ewes weighing about $60 \mathrm{~kg}$ were used in two experiments. In the first experiment, oats $(0,3 \mathrm{~kg} / \mathrm{day})$ were given during autumn mat- 
ing. In the second experiment a progesterone treatment was used to synchronize oestrus and 500 units PMSG were administered to the ewes.

TABLE 1

Plane of nutrition

\begin{tabular}{|c|c|c|c|c|c|}
\hline & & \multicolumn{2}{|c|}{ 1st period * } & \multicolumn{2}{|c|}{ 2nd period } \\
\hline & & $\begin{array}{c}\mathrm{Hay} \\
(\mathrm{kg} / \mathrm{d})\end{array}$ & $\begin{array}{l}\text { Concentrate } \\
(\mathrm{kg} / \mathrm{d})\end{array}$ & $\begin{array}{c}\mathrm{Hay} \\
(\mathrm{kg} / \mathrm{d})\end{array}$ & $\begin{array}{c}\text { Concentrate } \\
(\mathrm{kg} / \mathrm{d})\end{array}$ \\
\hline Experiment 1 & $\begin{array}{l}\text { High (12) } \ldots \ldots \\
\text { High-Low (12) } \\
\text { Low (12) ..... }\end{array}$ & $\begin{array}{l}1.0 \\
1.0 \\
0.7\end{array}$ & $\begin{array}{c}0.8 \\
0.8 \\
0\end{array}$ & $\begin{array}{l}1.0 \\
0.8 \\
0.8\end{array}$ & $\begin{array}{l}0.8 \\
0 \\
0\end{array}$ \\
\hline Experiment 2 & $\begin{array}{l}\text { High-Low }(14) \\
\text { Low }(14) \ldots \ldots\end{array}$ & $\begin{array}{c}\text { ad. lib } \\
1.0\end{array}$ & $\begin{array}{c}0.7 \\
0\end{array}$ & $\begin{array}{l}1.2 \\
1,2\end{array}$ & $\begin{array}{l}0 \\
0\end{array}$ \\
\hline
\end{tabular}

The number of ewes in each group is shown in parentheses.

* 1 st period : experiment $1=-14$ to -4 weeks prepartum ; experiment $2:-14$ to -6 weeks prepartum.

The plane of nutrition is given in table 1 . Natural grassland hay $(530 \mathrm{~g}$ DOM and $110 \mathrm{~g}$ crude protein per $\mathrm{kg} \mathrm{DM}$ ) and rye-grass hay (560 g DOM and $90 \mathrm{~g}$ crude protein per $\mathrm{kg} D M$ ) were used in the first and second experiments, respectively. The composition ( $p .100, w / w)$ of concentrate in the first experiment was : soya seed cake 20 , maize 50 , oats 15 , barley 15 ( $190 \mathrm{~g}$ crude protein per $\mathrm{kg} \mathrm{DM})$, and in the second experiment : soya seed cake 15 , barley 70 , maize 15 (170 g crude protein per $\mathrm{kg} D M)$. The ewes were fed at $8.30 \mathrm{~h}$ and $17.00 \mathrm{~h}$ and cll groups had straw ad libitum. Undernutrition was therefore very severe in the first experiment (about 80 p. 100 of maternal maintenance requirement assuming an intake of $300 \mathrm{~g}$ straw) while the maintenance requirement was fulfilled in the second experiment. In both experiments the nitrogen undernutrition was considerable since estimated digestible protein intake was about $40 \mathrm{~g}$ per ewe, as compared with $54 \mathrm{~g}$ for maintenance and more than $100 \mathrm{~g}$ needed in the later stages of twin pregnancy (Tissier and Theriez, 1978).

Biochemical techniques. - The heparinized blood samples were immediately centrifuged and frozen at $-20^{\circ} \mathrm{C}$. The determinations of the metabolite concentrations have been previously described (Rémésy and Demigné, 1976 ; Rémésy, Demigné and Aufrère, 1978).

\section{Results.}

In each group, only twin-pregnant ewes are considered, and the variations of maternal body weight and lambing results are given in table 2. In experiment 2, we distinguished normal and ketotic ewes; the threshold of ketosis was assumed to be higher than $1 \mathrm{mM}$ for 3 -hydroxybutyrate in the last 3 weeks of pregnancy. 
Maternal and lamb body weights (table 2).

In the first experiment, diet restriction during the second period caused a higher loss of weight in the « high-low » group than in the « low » group. The mobilization of body reserves occurred earlier in the low group. The undernourishment decreased the lamb birth weight similarly in the «low » and « high-low » groups but at lambing, ewe live weight (and thus lactation) was less affected in the «high-low » group.

TABLE 2

Changes in maternal body weight and lamb birth weight according to the plane of nutrition

\begin{tabular}{|c|c|c|c|c|c|c|}
\hline & & & \multirow{2}{*}{$\begin{array}{c}\text { Maternal } \\
\text { body weight } \\
\text { at - } 20 \text { weeks } \\
\text { prepartum } \\
(\mathrm{kg})\end{array}$} & \multicolumn{2}{|c|}{$\begin{array}{c}\text { Changes in maternal } \\
\text { body weight }\end{array}$} & \multirow{2}{*}{$\begin{array}{l}\text { Lamb } \\
\text { birth weight } \\
(\mathrm{kg})\end{array}$} \\
\hline & & & & $\begin{array}{l}\text { 1st period } \\
(\mathrm{kg})\end{array}$ & $\begin{array}{c}\text { 2nd period } \\
\qquad(\mathrm{kg})\end{array}$ & \\
\hline Experiment 1 & $\begin{array}{l}\text { High (7) } \\
\text { High-Low ( } \\
\text { Low (9) }\end{array}$ & & $\begin{array}{l}57.4 \pm 2.3 \\
59.4 \pm 3.2 \\
56.8 \pm 2.0\end{array}$ & $\begin{array}{r}-13.2 \\
-13.9 \\
-\quad 1.7\end{array}$ & $\begin{array}{r}+3.8 \\
-4.7 \\
-0.5\end{array}$ & $\begin{array}{l}3.80 \pm 0.20 \\
2.40 \pm 0.12 \\
2.50 \pm 0.14\end{array}$ \\
\hline Experiment 2 & High-Low & $\begin{array}{l}\text { Normal } \\
(5) \\
\text { Ketotic } \\
(2) \\
\text { Normal } \\
(4) \\
\text { Ketotic } \\
(3)\end{array}$ & $\begin{array}{l}62.0 \pm 3.5 \\
62.5 \pm 1.0\end{array}$ & $\begin{array}{r}-11.2 \\
+\quad 9.5\end{array}$ & $\begin{array}{l}+-1.4 \\
-2.0\end{array}$ & $\begin{array}{l}3.10 \pm 0.14 \\
2.95 \pm 0.18\end{array}$ \\
\hline
\end{tabular}

The number of twin-pregnant ewes in each group is shown in parentheses. In the experiment 1 , changes in maternal body weight were measured at -6 and -2 weeks prepartum and in the experiment 2 at -9 and -3 weeks prepartum.

In experiment 2, the dielary restriction was mild, as shown by the lamb birth weight; however, the ewes did not gain weight during the period of maximal foetal growth. All the animals which were to become ketotic presented the smallest increase in body weight in the first experimental period and the highest weight loss in the second period.

\section{Glucose, urea (fig. 1 and 3).}

The restricted twin-pregnant ewes showed comparable marked hypoglycaemia in both experiments. The increase in glycaemia after morning feeding was observed only in the ewes which received concentrate, or at the end of gestation in all groups (exp. 1). The ketotic ewes (exp. 2) were the most hypoglycaemic, and in all groups glycaemia decreased in the later stage of pregnancy.

In the two experiments, the initial differences in urea concentrations were caused by the quantities of nitrogen ingested. The urea decreased more markedly in the 
«low » group than in the « high-low » group at the end of gestation and in response to food restriction (exp. 1) ; the more detailed kinetics in experiment 2 show that the maximal drop in uremia usually occurred 2 weeks before parturition.
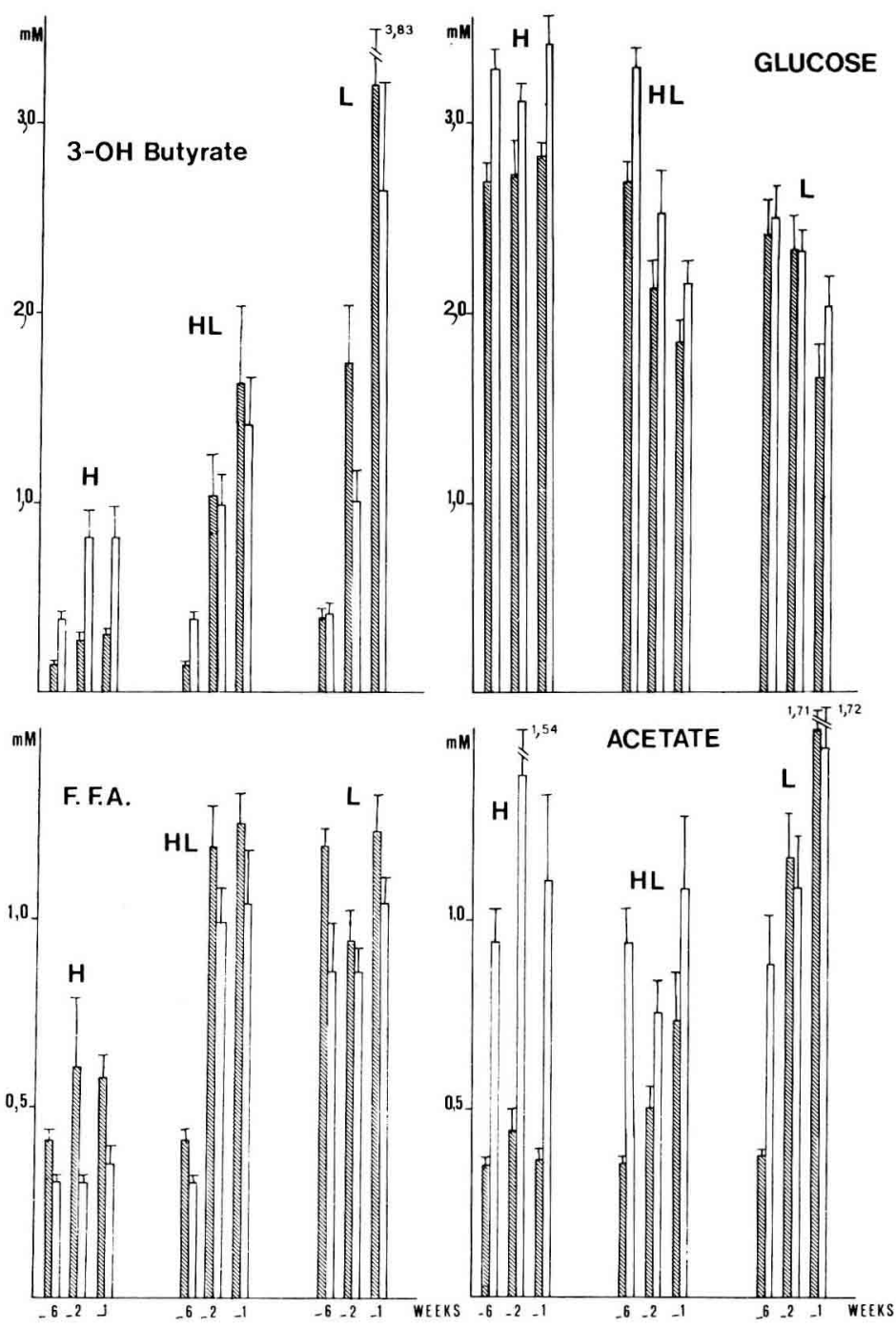

FIG. 1. - Variations of plasma metabolites according to the stage of pregnancy in twin pregnant ewes in the experiment 1 (see tables 1 and 2). Hatched bars correspond to sampling before morning feeding and open bars to sampling 3 hrs after feeding.

Free fatty acids, ketone bodies, acetate (fig. 1 and 2).

Lipomobilization always increased in hypoglycaemic ewes. The free fatty acids (FFA) augmented progressively during gestation and ketotic ewes showed the highest lipomobilization. The FFA and ketone bodies decreased after feeding in restricted 
ewes ; in contrast, in well-fed animals FFA decreased and ketone bodies increased after feeding because of the rumen ketogenesis from butyric acid (rumen content : acetate $76 \mathrm{mM}$, propionate $30 \mathrm{mM}$, butyrate $24 \mathrm{mM}$ in the « high » group and acetate $47 \mathrm{mM}$, propionate $12,5 \mathrm{mM}$, butyrate $4,2 \mathrm{mM}$ in the «low » group). Although FFA were similar in the two restricted groups, ketone bodies were higher in the «low » group than in the « high-low » group ; this fact was also observed in the second experiment for ketotic ewes. In the «high» and «high-low» groups there were postprandial increases in acetate but these changes were not observed in the «low » group in late pregnancy, and plasma acetate concentration was higher than in the well-nourished ewes (fig. 1). The increase of acetate at the end of gestation was highest in the most ketotic ewes (fig. 2).
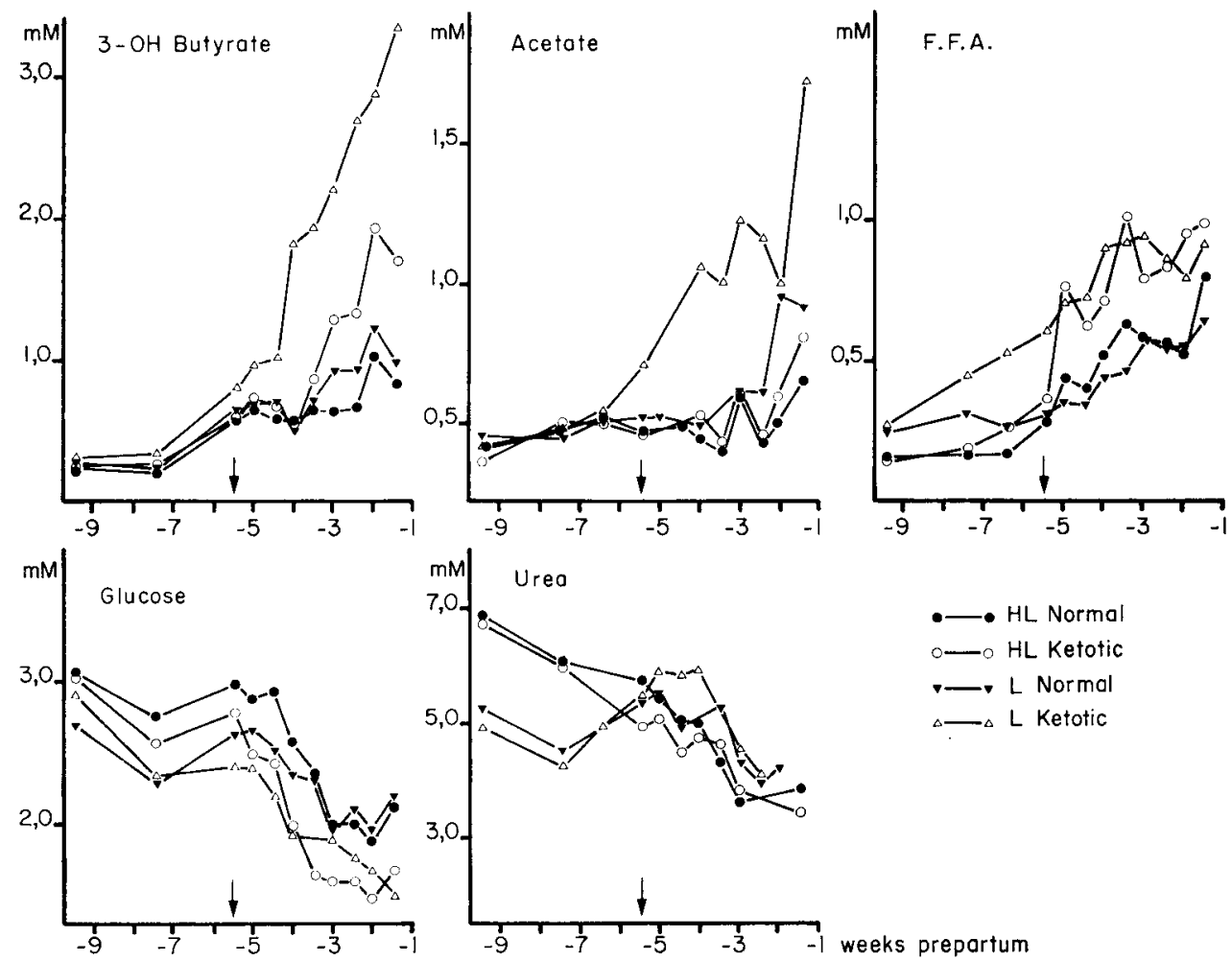

FIG. 2. - Plasma metabolite concentrations during late pregnancy after dietary restriction in the experiment 2 (see tables 1 and 2). The arrows indicate the change of diet.

Amino acids (fig. 3, table 3).

Alanine is low during gestation (Rémésy and Demigné, 1976). Alanine and urea were higher in the « high-low » group than in the « low » group at the beginning of the restriction (table 3 ) due to the more efficient mobilization of body protein reserves. In the second experiment we present an example of plasma amino acid variations at 8 and 2 weeks before lambing. Variations in the concentrations of most of the essential 
amino acids are very limited ; some essential acids, such as methionine, are very low during gestation. The most striking changes concern glycine which increased markedly with energetic and nitrogenous undernutrition.

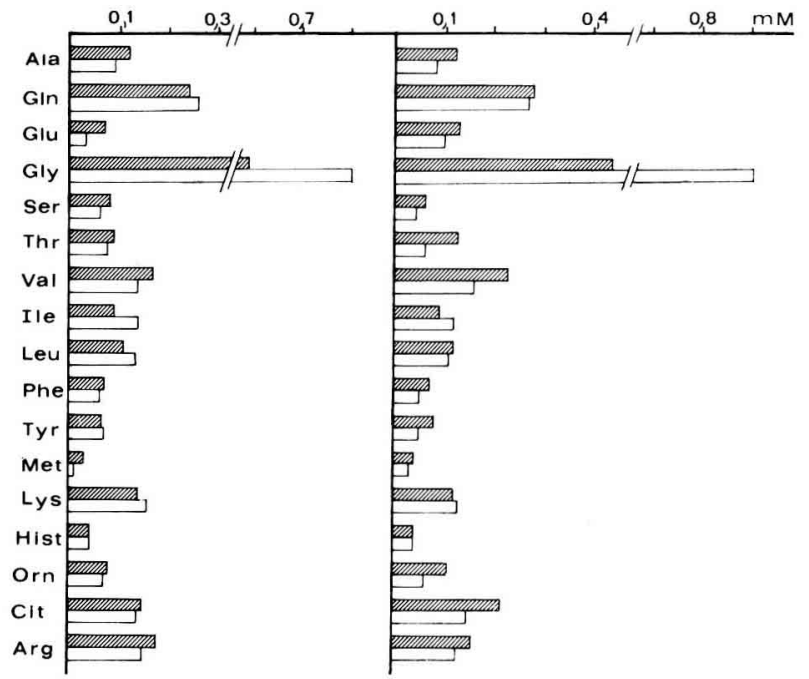

L

H L

(2) -8 weeks $\square-2$ weeks

FIG. 3. - Comparison of plasma amino acids (in $\mathrm{mM}$ ) at -8 and -2 weeks prepartum in the $H L$ and $L$ groups of ewes of the experiment 2 (Normal ewes (see tables 1 and 2)). Each value is the mean of three samplings before morning feeding during one week.

TABLE 3

Plosma alanine and urea in the first and second period of experiment 1

\begin{tabular}{|c|c|c|c|}
\hline Weeks prepartum & High group (7) & $\begin{array}{l}\text { High-low } \\
\text { group (7) }\end{array}$ & Low group (9) \\
\hline f Urea & $6.70 \pm 0.42 * * *$ & $6.70 \pm 0.42$ & $3.53 \pm 0.21^{* *}$ \\
\hline Alanine & $0.13 \pm 0.01$ & $0.13 \pm 0.01$ & $0.11 \pm 0.01$ \\
\hline Urea & $5.40 \pm 0.30 * * *$ & $4.07 \pm 0.19 *$ & $2.55 \pm 0.23 * *$ \\
\hline Alanine & $0.14 \pm 0.01 * * *$ & $0.16 \pm 0.01$ & $0.08 \pm 0.01 * *$ \\
\hline Urea & $5.60 \pm 0.45 * * *$ & $3.93 \pm 0.42 *$ & $2.10 \pm 0.23 * *$ \\
\hline Alanine & $0.14 \pm 0.02 * * *$ & $0.10 \pm 0.01$ & $0.08 \pm 0.01$ \\
\hline
\end{tabular}

Results are means (in $\mathrm{mM}$ ) \pm SEM for the number of ewes shown in parentheses.

The statistical significance of the differences between the groups $(P<0.05)$ is indicated by : * High vs High-Low group, and by ** High-Low vs Low group, *** High vs Low group. 


\section{Discussion,}

Effect of fatness during undernutrition on susceptibility to ketosis and foetal growth.

The energy intake during late pregnancy determines the lamb birth weight to a greater extent than the state of body reserves at mid-pregnancy. In contrast, the susceptibility to ketosis seems to be inversely correlated with the gain in live weight in the first two-thirds of gestation. We have not observed any detrimental effect of the fatness ; however fatness has only been estimated by the gain in gross body weight.

Glucose is the main energic fuel for the foetus when the glycaemia of the mother is normal, and twin foetuses use a considerable amount of glucose synthesized by the ewe (Silver, 1976). In maternal hypoglycemia, the ovine foetus is able to increase the utilization of amino acids (Simmons ef al., 1974), but at the expense of maternal gluconeogenesis. The foetal gluconeogenesis is weak (Prior and Christenson, 1977) and the only metabolic adaptation that could save glucose or glucogenic precursors, would be an increase in utilization of acetate or ketone bodies; however the use of ketone bodies in the foetal metabolism seems to be very limited (Morris et al., 1974). Utilization of acetate would be limited by the maternal foetal gradient, which is decreased by uteroplacental metabolism. However a high concentration of plasma acetate in the undernourished ewes favours acetate utilization by the foetus (Char and Creasy, 1976).

\section{Regulation of gluconeogenesis.}

The limiting factor of maternal gluconeogenesis during late pregnancy is the availability of amino acids, which are extensively used by the foetus. In the undernourished ewes, ruminal fermentation is poor in propionate and, despite a possible increase in the rate of conversion of propionate into glucose (Steel and Leng, 1973), amino acids are the main limiting substrates of gluconeogenesis. The part of glycerol liberated by lipolysis may exceed 20 p. 100 of the synthesized glucose (Bergman, Starr and Reulein, 1968), only if the availability of amino acids is considerably decreased and glucose furnover low. Lactate utilization does not correspond to a net glucose synthesis ; however, increased recycling of glucose into lactate permits saving the glucose in peripheral tissues. Previous observations have shown that foetal growth is moderately affected by nitrogen undernutrition when energy intake is adequate (Robinson ef al., 1970). This fact would agree with the relative constancy of plasma essential amino acids after dietary restriction. An increased nitrogen supply could be favorable for the ewe by stimulating hepatic gluconeogenesis while impairing proteolysis. Whilst plasma alanine, glutamate, serine and threonine decreased during dietary restriction, glutamine was unchanged. In the starved sheep, glutamine release by peripheral tissues would be doubled and, in acidosis, renal utilization is predominant at the expense of hepatic utilization (Heitmann and Bergman, 1978) ; this fact must be taken into account in ewes with ketoacidosis. The plasma alanine is low when ketogenesis occurs, whereas hepatic alanine concentration decreased at the end of gestation (Herriman ef al., 1976). This point agrees with the strongly antiketogenic action of alanine in the ruminant (Demigné and Rémésy, 1977). The increase in glycine described in the case of energy 
and nitrogenous deficiency in the rat (Ishikawa, 1975) also occurs in the same conditions in the ewe. Inhibition of glycine synthase by branched-chain $\alpha$-ketoacids originating from muscular proteolysis is a possible mechanism for glycine accumulation (O'Brien, 1978). The reduction in urea excretion during late pregnancy (Robinson, Scott and Fraser, 1973) may arise from a smaller release of amino acids from maternal tissues or an increased storage, a higher uptake of amino acids by the foetus, or an enhanced urea recycling to the rumen (Nolan and Leng, 1970). This last mechanism could account for the positive effect on nitrogen retention of an increase in metabolizable energy intake (Guada, Robinson and Fraser, 1975). An enhanced production of propionic acid in the rumen would decrease gluconeogenesis from amino acids, but it is unlikely that gluconeogenesis from amino acids diminishes at the end of gestation, even in well nourished animals since glucose utilization by the foetus is very high. When pregnant ewes are submitted to a short period of submaintenance feeding, they excrete more urea than non pregnant animals (Graham, 1968). However, a progressive decrease in nitrogen catabolism may occur (Guada, Robinson and Fraser, 1976), if the restriction period is prolonged; this is a well-established phenomenon during starvation or undernourishment (Cahill and Owen, 1968). The decrease in amino acid supply certainly causes lower gluconeogenesis. These changes in substrate availability are accompanied by hormonal changes, particularly the decrease of insulinaemia and the increase in growth hormone (Hove and Blom, 1976). Furthermore, glucagon secretion is mainly postprandial and undernourishment could result in an insufficient glucagon secretion as hypoglycemia seems a less potent stimulus of secretion in ruminants (Brockman, 1977).

\section{Regulation of ketogenesis.}

Fatness seems to have a slight influence on the plasma FFA concentration. In overfat ewes, peripheral utilization is probably higher than kepatic uptake due to abundance of glycogenic substrats which favour reesterification (Heimberg ef al., 1974). In underfat ewes, the mobilization of FFA is still efficient but the availability of amino acids is low: hepatic uplake and ketogenesis are favoured. In the liver, the reesterification pathway and the release of triglycerides as lipoproteins is inhibited by a lack of insulin (Nikkila, 1974). These changes could result in a fatty liver (Smith and Walsh, 1975). Mc Garry, Wright and Foster (1975) have emphasized the role of the carnitine acyl transferase and insulin/glucagon ratio in the control of ketogenesis. Glucagon is probably important in the ketotic ewe, as in diabetics, since it is an activator of lipolysis and ketogenesis when insulin is low (Brockman, 1976).

The decrease in activity of tricarboxylic cycle arises from the shortage of oxaloacetate and particularly from the inhibition exerted by the energy produced in the $\beta$-oxidation. The production of endogenous acetate is another pathway for removal of excess hepatic acetyl CoA via acetyl carnitine (Costa, Mc Intosh and Snoswell, 1976) when lipogenesis is not active. The accumulation of plasma acetate arises from a lack of insulin and glucose for its utilization by peripheral tissues. 
Résumé. L'objectif de cette étude est de montrer les interactions entre la mobilisation des réserves protéiques et lipidiques sur la néoglucogenèse et la céłogenèse en cas de restriction alimentaire chez la brebis en fin de gestation. Deux expériences sur des brebis Limousines porteuses de doubles ont été réalisées ; la sous-nutrition durait pendant les 14 dernières semaines de la gestation ou 4 à 6 dernières semaines selon les lots ( 80 à 100 p. 100 des besoins d'entretien). L'énergie ingérée en fin de gestation conditionne le poids des agneaux à la naissance beaucoup plus nettement que les réserves corporelles au milieu de la gestation. Par contre la susceptibilité aux cétoses est inversement proportionnelle au gain de poids de la mère durant les 2 premiers tiers de la gestation. Les acides aminés sont les facteurs limitants de la néoglucogenèse maternelle lorsque la production d'acide propionique est faible. Ceci se traduit par la baisse de certains acides aminés glucoformateurs (surtout l'alanine) particulièrement en cas de sous-nutrition ; la glycine par contre s'élève et la modification des acides aminés essentiels est variable et de faible amplitude. La mobilisation protéique est plus élevée dans les lots « haut-bas » que dans les lots « bas » et ceci se traduit par une cétogenèse plus faible dans les lots « haut-bas » pour une même concentration en acides gras libres plasmatiques. En fin de gestation l'acétate plasmatique s'élève en même temps que les corps cétoniques à la suite d'une production endogène et d'une moindre utilisation par les tissus périphériques.

\section{References}

BERGMAN E. N., STARR D. J., REULEIN S. S. Jr., 1968. Glycerol metabolism and gluconeogenesis in the normal and hypoglycemic ketotic sheep. Am. J. Physiol., 215, 874-880.

BROCKMAN R. P., 1976. Effects of glucagon and insulin on lipolysis and ketogenesis in sheep. Can.J. comp. Med., 40, 166-170.

BROCKMAN R. P., 1977. Glucose-glucagon relationships in adult sheep. Can. J. comp. Med., 41, 95-97.

CAHILL E. F. Jr., OWEN O. E., 1968. in DICKENS F., RANDLE P. J., WHELAN W. J., Carbohydrafe metabolism and its desorders. Acad. Press Inc., New York, 1968.

CHAR V. C., CREASY R. K., 1976. Acetate as a metabolic substrate in the foetal lamb. Am. J. Physiol., 230, 357-361.

COSTA N. D., McINTOSH G. H., SNOSWELL A. M., 1976. Production of endogenous acetate by the liver in lactating ewes. Austr. J. biol. Sci., 29, 33-42.

DEMIGNÉ C., REMÉSY C., 1977. La cétogenèse chez le ruminant à jeun : influence des acides gras volatils, du glucose et de l'alanine. Ann. Biol. anim. Bioch. Biophys., 17, 887-895.

GRAHAM N. Mc, 1968. Effects of undernutrition in late pregnancy on the nitrogen and energy metabolism in ewes. Austr. J. agric. Res., 19, 555-565.

GUADA J. A., ROBINSON J. J., FRASER C., 1975. The effect of dietary energy concentration on protein utilization during late pregnancy in ewes. J. agri. Sci. Camb., 85, 175-183.

GUADA J. A., ROBINSON J. J., FRASER C., 1976. The effect of a reduction in food intake during late pregnancy on nitrogen metabolism in ewes. J. agri. Sci. Camb., 86, 111-116.

HEIMBERG M., WILCOX H. C., DUNN D., WOODSIDE W. F., BREEN K. J., SOLER ARGILAGA C., 1974. Studies on the regulation of secretion of the very low density lipoprotein and on ketogenesis by the liver, 119-141. In LUNDQUIST F., TYGSTRUP N., Regulation of hepatic metabolism, A. Benzon Symp. VI, Munskgaard, Copenhagen.

HEITMANN R. N., BERGMAN E. N., 1978. Glutamine metabolism, interorgan transport and glucogenicity in the sheep. Am. J. Physiol., 234, E 197-E 203.

HERRIMAN I. D., HEITZMANN R. J., PRIESTLEY I., SANDHU G. S., 1976. Concentration of intermediate metabolites in the blood and hepatic tissues of pregnant and non-pregnant ewes. J. ogric. Sci. Camb., 87, 407-411.

HOVE K., BLOM A. K., 1976. Plasma insulin and growth hormone concentrations in pregnant sheep. Acta endocr., 82, 544-552.

ISHIKAWA E., 1975. The regulation of uptake and output of amino acids by rats tissues. Adv. Enzyme Regul., 14, 117-136.

MCGARRY J. D., WRIGHT P. H., FOSTER D. W., 1975. Hormonal control of ketogenesis. Rapid activation of hepatic ketogenic capacity in fed rats by anti-insulin serum and glucagon. J. clin. Invest., 55, 1202-1209.

MORRIS F. H., BOYD R. D., MAKOWSKI E. L., MESCHIA G., BATTAGLIA F. C., 1974. Umbilical V-A differences of acetoacetate and 3 hydroxybutyrate in fed and starved ewes. Proc. Soc. exp. Biol. Med., 145, 879-883. 
NIKKILA E. A., 1974. Regulation of hepatic production of plasma triglycerides by glucose and insulin, 370-376. In LUNDQUIST F., TYGSTRUP N., Regulation of hepatic metabolism, A. Benzon Symp. VI, Munskgaard, Copenhagen.

NOLAN J. V., LENG R. A., 1970 . Metabolism of urea in late pregnancy and the possible contribution of amino acid carbon to glucose synthesis in sheep. Br. J. Nutr., 24, 905-915.

O'BRIEN W. E., 1978. Inhibition of glycine synthase by branched-chain $\alpha$-keto acids. Arch. Biochem. Biophys., 189, 291-297.

PRIOR R. L., CHRISTENSON R. K., 1977. Gluconeogenesis from alanine in vivo by the ovine foetus and lamb. Am. J. Physiol., 233, E 462-E 468.

RÉMÉSY C., DEMIGNÉ C., AUFRĖRE J., 1978. Inter-organ relationships between glucose, lactate and amino acids in rats fed on high-carbohydrate or high-protein diets. Biochem. J., 170, 321-329.

RÉMÉSY C., DEMIGNÉ C., 1976. Variations in some plasma metabolites from gluconeogenesis and ketogenesis in pregnant ewes in relation to diet. Ann. Rech. vétér., 7, 329-341.

REID R. L., 1968. The physiopathology of undernourishment in pregnant sheep, with particular reference to pregnancy toxaemia. Adv. vet. Sci., 12, 163-226.

ROBINSON J. J., FRASER C., CORSE E. L., GILL J. C., 1970. The effect of pattern of protein intake and level of energy intake on the performance and nitrogen utilization of the ewe. J. ogric. Sci., Camb, 75, 403-411.

ROBINSON J. J., SCOTT D., FRASER C., 1973. Observations on the effect of protein intake and stage of gestation on the proportion of urinary nitrogen excreted as urea in sheep. J. agric. Sci. Camb., 80, 363-368.

ROBINSON J. J., MCDONALD I., FRASER C., CROFTS R. M. J., 1977. Studies on reproduction in prolific ewes. J. agric. Sci. Camb., 88, 539-552.

RUSSEL A. J. F., DONEY J. M., REID R. L., 1967. The use of biochemical parameters in controlling nutritional state in pregnant ewes, and the effect of undernourishment during pregnancy on lamb birth-weight. J. agric. Sci. Camb., 68, 351-358.

SILVER M., 1976. Foetal energy metabolism, 173-193. In BEARD R. W., NATHANIELSZ P. W., Foefal physiology and medicine, Saunders, London.

SIMMONS M. A., MESCHIA G., MAKOWSKIE. L., BATTAGLIA F., 1974. Foetal metabolic response to maternal starvation. Pediat. Res., 8, 830-836.

SMITH R. W., WALSH A., 1975. The composition of the liver lipids of the ewe during pregnancy and lactation. Res. vef. Sci., 19, 230-232.

STEEL J. W., LENG R. M., 1973. Effects of plane of nutrition and pregnancy on gluconeogenesis in sheep. II. Synthesis of glucose from ruminal propionate. Br. J. Nutr., 30, 475-489.

TISSIER M., THERIEZ M., 1978. Ovins, 403-448. In Alimentation des ruminants, Ed. INRA Publications (route de Saint-Cyr), 78000 Versailles. 